\title{
El reúso colonial de los janamus en Tzintzuntzan, Michoacán Una exaltación del pasado prehispánico
}

\begin{abstract}
D ste trabajo se dedica a losas con motivos grabados empleadas por 7 los tarascos como revestimiento arquitectónico en dos espacios de 1 carácter ceremonial ubicados en Tzintzuntzan, Michoacán. Se trata, en términos actuales, de la zona arqueológica y del ex convento de San Francisco. En el idioma purépecha, dichas losas se llaman janamus $;{ }^{\mathrm{I}}$ originalmente se usaron en el antiguo centro ceremonial y después de la Conquista se reutilizaron en el templo cristiano. Se pretende exponer aquí información sobre las imágenes plasmadas en los janamus y su relación directa con las construcciones y el arte rupestre; asimismo, referir los rituales religiosos y otras actividades sociales que tenían lugar en cada recinto. Una vez planteada su importancia durante la época prehispánica, el énfasis se pone en la reutilización de estas obras en el marco de una recuperación del pasado antiguo, vinculado con la memoria histórica y los afanes de la antigua elite purépecha de Tzintzuntzan por conservar sus privilegios políticos y económicos después de la Conquista.
\end{abstract}

I. En un diccionario del siglo XVI, janamu se traduce como "piedra áspera"; véase Maturino Gilberti, Vocabulario en lengua de Mechuacan compuesta por el Reverendo Padre fray Maturino Gilberti de la Orden del Seráfico Padre San Francisco, Morelia, Balsal, I983, p. I 49 [primera ed. I 559]. 
DOI: http://dx.doi.org/10.22201/iie.18703062e.2010.96.2305

6

VERÓNICA HERNÁNDEZ DÍAZ

El antiguo centro ceremonial tarasco y sus janamus decorados

Tzintzuntzan está situado en la ribera oriente del lago de Pátzcuaro. Ahí se asentaba la capital principal del imperio tarasco a la llegada de los españoles hacia I522; las ciudades capitales secundarias eran Ihuatzio y Pátzcuaro. ${ }^{2}$ En el México precolombino, los tarascos sobresalen durante los dos siglos anteriores a la ocupación europea; su dominio abarcó la mayor parte del actual territorio de Michoacán y sectores colindantes de Guanajuato, Jalisco y Guerrero; los distinguen su belicosidad, explotación minera y producción metalúrgica; conforman un pueblo de composición multiétnica, a cuya cabeza estaban los purépechas. ${ }^{3}$

La sección principal del antiguo centro ceremonial de Tzintzuntzan, abierta al público, se ubica en la "gran plataforma", un colosal basamento artificial erigido en la ladera baja del cerro Yahuarato (fig. I), que mide $250 \times 450 \mathrm{~m}$ de frente. Dicha sección se orienta al lago y presenta una rampa amplia que servía de acceso. ${ }^{4}$ Sobre la plataforma se ve una vasta explanada — con capacidad para alojar a millares de personas - y apenas unos cuantos edificios. Los más importantes, y a la vez imponentes, son las cinco yácatas, nombre purépecha dado a las pirámides o montículos de piedra antiguos;'s se disponen alineadamente sobre un basamento común y las separa un pasillo angosto;

2. Helen P. Pollard, Tariacuri's Legacy: The Prehispanic Tarascan State, Norman, University of Oklahoma Press, I993, p. 29.

3. Además de los purépechas comprendía grupos mazahuas, otomíes, nahuas, chontales, apanecas y cuicatecas; véase Ulises Beltrán, "Estado y sociedad tarascos en la época prehispánica", en Brigitte Boehm de Lameiras (coord.), El Michoacán antiguo: Estado y sociedad tarascos en la época prehispánica, Zamora, Gobierno del Estado de Michoacán/El Colegio de Michoacán, I994, p. 53.

4. Pollard, op. cit., p. 47. A la fecha, arqueólogos como Jorge R. Acosta, Rubén Cabrera Castro, Helen Perlstein Pollard y Efraín Cárdenas García han realizado io temporadas arqueológicas en el sitio, más otras dos de estudios de superficie. El público tiene acceso a sólo una parte de los vestigios identificados dentro de los límites oficiales de la zona arqueológica, los monumentos no han sido estudiados y restaurados en su totalidad.

Además de la gran plataforma, otras dos áreas más pequeñas conforman el centro ceremonial: una se ubica al este de ella y la otra más arriba; en la pendiente del cerro Yahuarato hay una terraza con dos basamentos piramidales de planta rectangular.

5. Nicolás León, "Sobre la significación de la palabra yácata”, en Angelina Macías (comp.), Lorena Mirambell (coord.), La arqueología en los Anales del Museo Michoacano (épocas I y II), México, Instituto Nacional de Antropología e Historia (Antologías, Serie Arqueología), I993, p. I 7 [primera ed. I888]. 


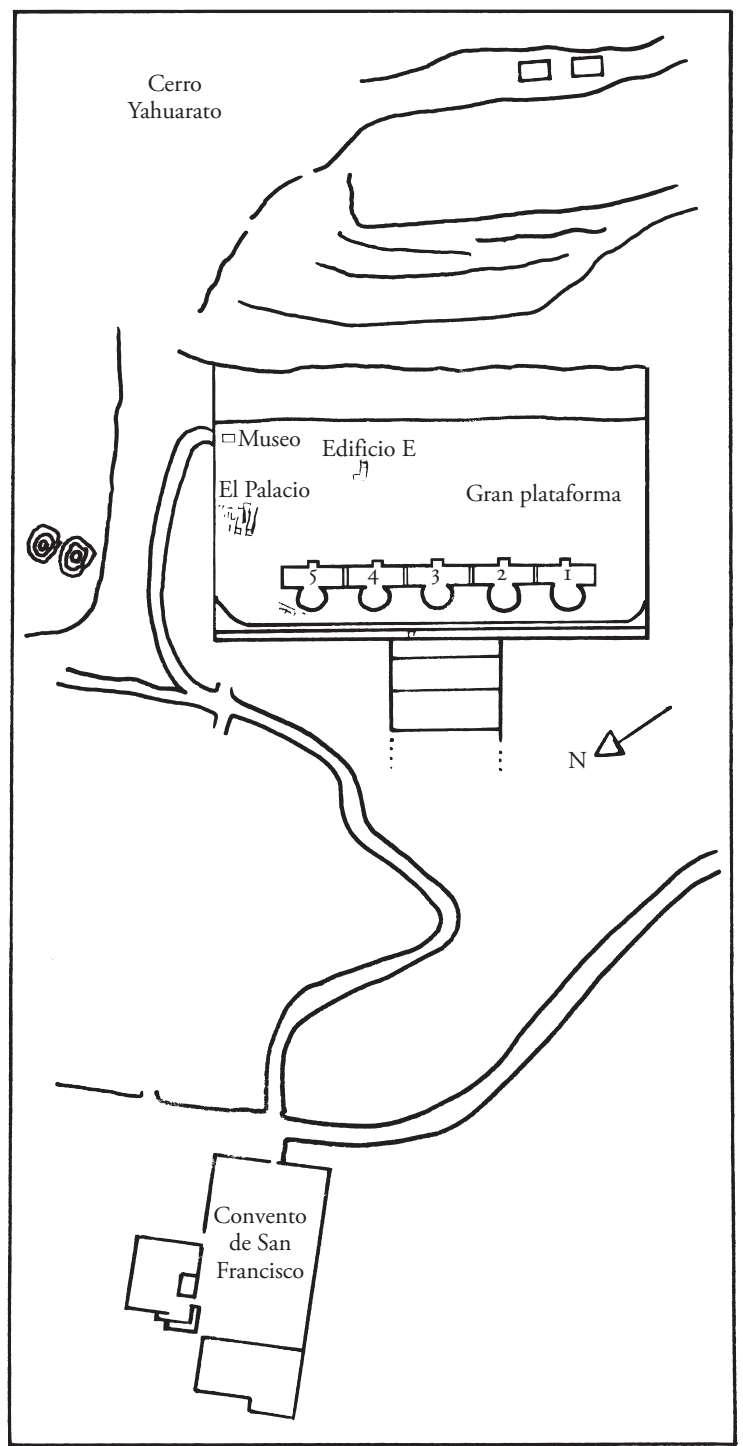

I. Plano de la zona arqueológica de Tzintzuntzan con el convento de San Francisco al pie del cerro Yahuarato. Dibujo de Verónica Hernández Díaz, basado en Cabrera Castro, op. cit., fig. I (infra n. 6); Pollard, op. cit., p. 48 (supra n. 2), y Foster, op. cit., plano frente a p. 56 (infra n. 27). 
la planta de cada una combina el rectángulo y el semicírculo, esta parte se ubica del lado dirigido hacia el lago - el norte. El largo de las cinco yácatas supera los $300 \mathrm{~m}$ y el ancho de cada una los $40 \mathrm{~m}$. Las conforman varios cuerpos escalonados de cerca de I $\mathrm{m}$ de alto, y se deduce que alcanzaban I 2 o I3 m de altura y que arriba había templos construidos con materiales perecederos. ${ }^{6}$ El ascenso a cada pirámide se hacía por una escalinata ubicada en la parte media de la sección rectangular. El resto de los edificios plenamente identificados sobre la gran plataforma se sitúa en la parte sureste. Se trata del Palacio o Edificio B y del Edificio E. El primero es una serie de cuartos en torno a un patio pequeńo con columnas y pilares, considerado la residencia de los sacerdotes; ${ }^{7}$ el segundo consta de cinco cuartos sin acceso y alineados en escuadra que pudieron funcionar como almacenes. ${ }^{8}$

De acuerdo con las evidencias arqueológicas, puede decirse que una característica de la arquitectura tarasca es que las pirámides estaban totalmente revestidas de janamus: lajas de piedra basáltica o volcánica, de forma cuadrangular y principalmente rectangular, y de superficie pulida (fig. 2).9 Sólo una parte de los janamus muestra diseños grabados o en bajorrelieve.

En la zona arqueológica de Tzintzuntzan he registrado 32 losas decoradas: 2I asociadas con las yácatas, 2 empotradas en los muros del Edificio E y 9 que se exhiben exentas en el museo del sitio. ${ }^{10}$ Entre las que me fue posible medir, la más grande alcanza $73 \times 58.5 \mathrm{~cm}$ y la menor $24.5 \times 34.2 \mathrm{~cm}$, y su espesor aproxi-

6. Rubén Cabrera Castro, “Tzintzuntzan, décima temporada de excavaciones”, en Barbro Dahlgren et al. (orgs.), Homenaje a Román Piña Chan, México, Universidad Nacional Autónoma de México-Instituto de Investigaciones Antropológicas, I987, p. 536.

7. Pollard, op. cit., p. 47. De este edificio se sabe que sus espacios sufrieron ampliaciones y disminuciones y que continuó ocupado durante los primeros años de la época virreinal (Cabrera Castro, op. cit., pp. 545-547).

8. Ibidem, pp. 547-55 I.

9. También se registraron los janamus en etapas constructivas más tempranas de las yácatas. Calas arqueológicas practicadas alrededor de la yácata número tres permitieron advertir subestructuras más tempranas; se infirió que se trataba de una plataforma donde se asienta el volumen circular de una yácata; se desconoce si su planta es también mixta y si había más. En el recubrimiento de esta yácata temprana pueden verse los janamus, que no están grabados y cuyas dimensiones son más reducidas que las de los janamus de las yácatas posteriores (Cabrera Castro, op. cit., pp. 538-543).

ı. Estas cantidades resultan de investigación realizada in situ y bibliográfica. La primera la efectué en dos ocasiones: en mayo de 2000 y en octubre de 2008. De ahí que en una publicación anterior el número de janamus que reporté sea menor. El estudio inicial de los janamus decorados lo presenté en "Los janamus grabados en la arquitectura prehispánica y virreinal de Tzintzuntzan, 


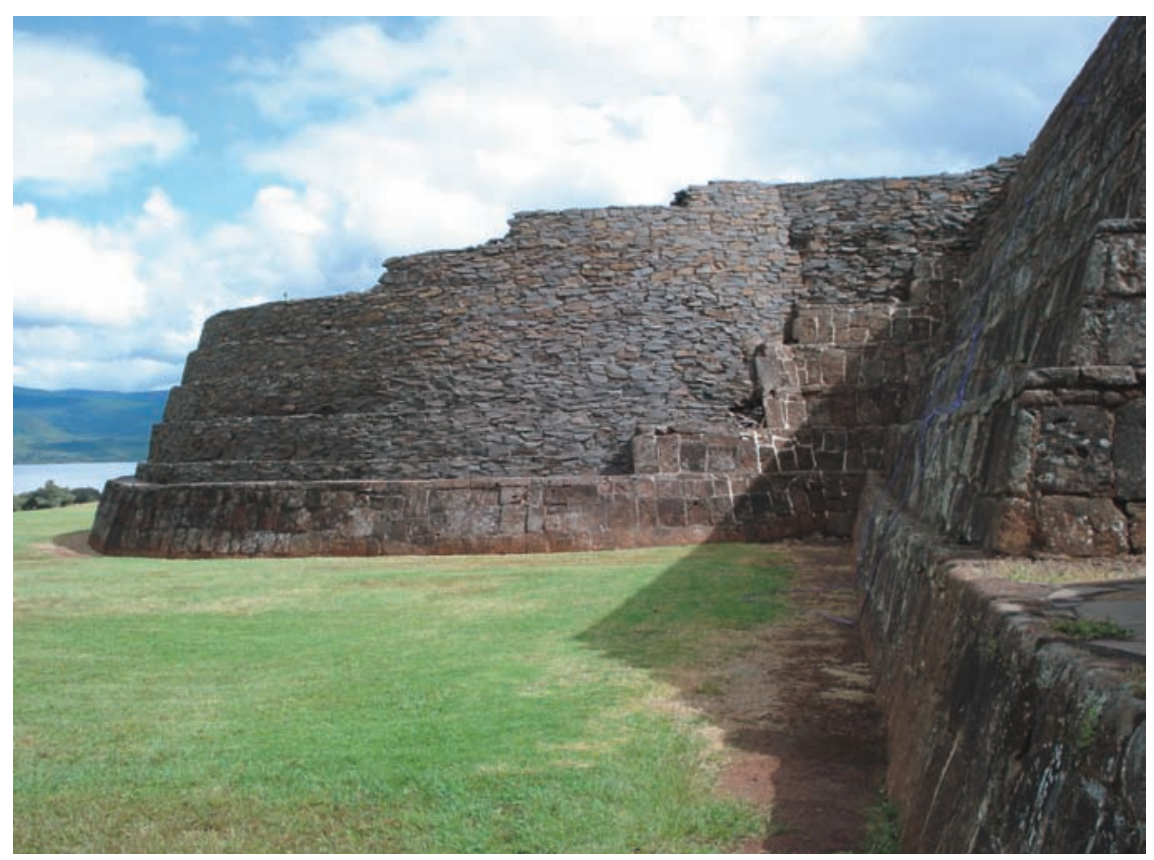

2. Yácata de la zona arqueológica de Tzintzuntzan. Después de los trabajos arqueológicos de restauración, parte de la superficie se recubrió con los janamus que originalmente la revestían toda. Foto: Verónica Hernández Díaz, 2008.

mado es de $15 \mathrm{~cm}$. Es necesario subrayar la imposibilidad de emitir consideraciones cuantitativas o cualitativas con carácter definitivo sobre estas obras, debido a su evidente movilidad luego de la Conquista, e incluso en tiempos recientes a raíz de los trabajos arqueológicos en el sitio. Durante el proceso de estudio tal aspecto se tomó en cuenta. ${ }^{\mathrm{II}}$ En tanto, cabe pensar que en tiempos

Michoacán”, tesis de Maestría en Historia del Arte, México, Universidad Nacional Autónoma de México-Facultad de Filosofía y Letras, 2006.

I I. En 1937-1938, cuando se practicaron las primeras excavaciones arqueológicas, las yácatas estaban muy deterioradas a causa del saqueo de materiales destinados a la construcción y de la búsqueda de tesoros (Jorge R. Acosta, "Exploraciones arqueológicas realizadas en el estado de Michoacán durante los años de 1937 y I938”, Revista Mexicana de Estudios Antropológicos, t. III, núm. 2, mayo-agosto de I939, pp. 85-86). En consecuencia, la mayor parte de los janamus grabados que revisten actualmente las yácatas no se encuentran en su posición original, puesto que fue necesario rehacer éstas. No obstante, sí se ha comprobado su asociación directa: el hallazgo 
prehispánicos la mayoría de los janamus decorados que originalmente se localizaban en el centro ceremonial estaban empotrados en las yácatas. Al parecer, en la actualidad las que se encuentran en los extremos del basamento mencionado (las números I y 5, según el plano del sitio) son las que se asocian con la mayor cantidad de losas ornamentadas: seis cada una.

El estilo de los diseños plasmados en los janamus es geométrico y, de acuerdo con nuestra percepción cultural, en su mayor parte puede considerarse no figurativo, debido a que predominan las espirales de diversos tipos, ya sea con un solo giro (simple), con un giro y radiados, con dos giros que se dirigen hacia un mismo punto (dobles convergentes) o con dos giros que siguen direcciones contrarias (dobles divergentes). Hay también otras formas curvas. Asimismo, círculos, algunos tallados como pozos y otros concéntricos; un diseño circular concéntrico y radiado; sólo una de las formas tiene apariencia humana (fig. 3). Entre el repertorio de diseños en la zona arqueológica, el más frecuente es la espiral doble divergente, presente en 13 casos.

Las losas decoradas se empotraron de modo disperso en las construcciones, en apariencia sin seguir un orden particular. Además, resulta significativo que los motivos no observen, en lo general, una disposición predominante en las losas; es decir, sólo ocupan una porción de la superficie, en ocasiones pequeña, y en muchos casos no se ubican en el centro.

En contraste con su apariencia "sencilla", conviene subrayar que se trata de un arte oficial que formó parte de la arquitectura tarasca de la más alta jerarquía, y no sólo de la ciudad de Tzintzuntzan, sino de todo el Estado tarasco, en razón de que aquélla era la capital principal y, por ende, el centro ceremonial más importante en el momento de la Conquista. En afinidad con ello, se advierte una minuciosa laboriosidad en la manufactura: todos los janamus, decorados o no, están cortados con precisión y tienen los cantos rebajados en ángulos rectos con el fin de que el mortero que servía para adosarlos al cuerpo de las pirámides quedara oculto en la superficie y en el exterior sólo se viera la juntura inmediata de las losas; igualmente, las piedras se aprecian finamente pulidas, y las que muestran imágenes exhiben trazos definidos y profundos. No hay indicios de que los janamus estuvieran cubiertos por algún tipo de apla-

arqueológico de losas decoradas entre los escombros superficiales de las yácatas hizo suponer que recubrían los monumentos, lo cual quedó en evidencia durante la segunda temporada, cuando Jorge R. Acosta descubrió algunos in situ (ibidem). Aunado a ello, durante la décima temporada, Rubén Cabrera Castro encontró en su lugar original - la yácata 3- otros janamus decorados; véase Cabrera Castro, op. cit., pp. 53 I-565. 

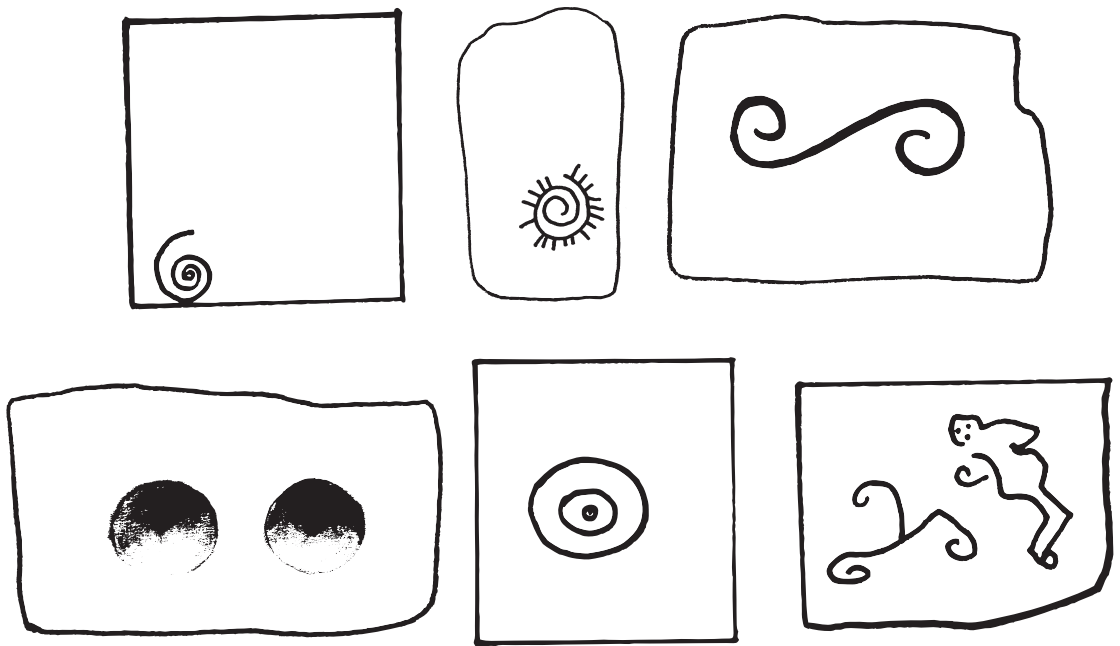

3. Janamus decorados registrados en la zona arqueológica de Tzintzuntzan. Dibujo: Verónica Hernández Díaz.

nado, de tal modo que sus diseńos se hallaban a la vista de la colectividad que transitaba por los espacios abiertos situados en la periferia de las yácatas.

En la Relación de Michoacán, ${ }^{\mathrm{I} 2}$ un documento del siglo xvI, la gran plataforma es referida como "patio de los cinco cues grandes", en alusión directa a los elementos más destacados de este centro ceremonial: la explanada y las yácatas. El mismo texto permite inferir que estas últimas estaban dedicadas a Curicaueri, suprema deidad tarasca vinculada con el Sol y el Fuego. Vale la pena citar un fragmento de la tercera parte, que narra el encuentro "pacífico" entre el conquistador español Cristóbal de Olid y su ejército con los tarascos en "Api", sitio ubicado a "media legua" de Tzintzuntzan:

llegaron todos a los patios de los cues grandes y soltaron allí los tiros. Y cayéronse todos los indios en el suelo, de miedo, y empezaron a escaramuzar en el patio que era muy grande.

I2. Su título completo es Relación de las ceremonias y ritos y población y gobierno de los indios de la Provincia de Michoacán. Comúnmente llamada Relación de Michoacán, la obra está conformada por texto y 44 láminas pintadas. El original se encuentra en la Biblioteca del Monasterio Agustino de El Escorial, en Espańa. 
Y fueron después a las casas del cazonci y viéronlas y tornáronse al patio de los cinco cues grandes y aposentáronse en las casas de los papas [el Palacio o Edificio B], que tenían diez varas — que ellos llaman pirimu — en ancho, y en los cues, que estaban a las entradas de los cues, y las gradas llenas de sangre del sacrificio que habían hecho. Y aún estaban por allí muchos cuerpos de los sacrificados. Y llegábanse los españoles y mirábanles si tenían barbas. Y como subieron a los cues, echaron las piedras del sacrificio a rodar, por las gradas abajo, y a un dios que estaba allí llamado Curitacaheri, mensajero de los dioses. ${ }^{13}$

Es oportuno hacer un paréntesis y recordar que la Relación de Michoacán es un documento sumamente valioso para conocer la historia y los antiguos rituales tarascos, así como sucesos iniciales de la dominación hispana. La versión de los hechos ahí narrados se atribuye al linaje dirigente asentado en Tzintzuntzan; de acuerdo con J. Benedict Warren, fue elaborada entre I539 y I543 aproximadamente; el autor, traductor y compilador fue el franciscano Jerónimo de Alcalá. ${ }^{\mathrm{I}}$

De modo especial, la Relación de Michoacán nos informa de solemnes rituales que tenían lugar en el centro ceremonial. Sobresale el funeral del soberano tarasco, que comprendía procesiones encabezadas por sacerdotes que tocaban "cornetas" y caracoles, el sacrificio de la comitiva que acompañaría al irecha o rey en su destino final, la cremación del cuerpo de este último y, finalmente, su entierro con los restos lujosamente ataviados y colocados dentro de una olla al pie de las yácatas. En asociación con estos monumentos y otros vestigios arquitectónicos de la gran plataforma, los arqueólogos han encontrado alrededor de 60 entierros con ricas ofrendas de objetos de cerámica, cobre, oro, madera,

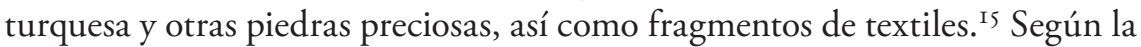
Relación de Michoacán, parte de tales entierros correspondía a los miembros de

I 3. Jerónimo de Alcalá, La relación de Michoacán, versión paleográfica, separación de textos, ordenación coloquial, estudio preliminar y notas por Francisco Miranda, México, Secretaría de Educación Pública (Cien de México), I988, p. 3 I 2 (subrayado de la autora) [primera ed. ca. I 539I 54I]. El sacrificio aquí referido fue el de "ochocientos esclavos" que tenían encarcelados los tarascos "porque no se les huyesen con la venida de los españoles y se hiciesen con ellos".

I4. J. Benedict Warren, Estudios sobre el Michoacán colonial. Los inicios, Morelia, Universidad Michoacana de San Nicolás de Hidalgo-Instituto de Investigaciones Históricas/Fimax, 2005, pp. I 55-1 86 (dichos datos los publicó primero el autor en 1971).

I 5. Cabrera Castro, op. cit., pp. 560-564. La mayoría de los entierros fueron saqueados por los españoles inmediatamente después de la conquista de Michoacán, como lo refieren documentos históricos y lo corroboran las excavaciones arqueológicas (ibidem, p. 562). 
la elite purépecha dirigente y a otros a individuos de jerarquía menor que eran sacrificados en honor a los primeros.

Otros rituales más cotidianos consistían en encender fuego con leña para producir humo y venerar a Curicaueri, y asimismo, mediante oraciones, implorar su ayuda para las campañas bélicas que emprendían, tal como consta en el siguiente pasaje:

Entonces un sacerdote llamado hiripati, y cinco de los sacrificadores y cinco de otros sacerdotes llamados curitiecha, hacían unas pelotillas de olores, en una casa que estaba en su casa del cazonci, y poníanlas en unas rajas de encina y después ponían todas aquellas pelotillas de aquellos olores en unas calabazas y dábanles unas cazuelas y unos cañutos de sahumerios y llevaban aquellas cazuelas al hombro cinco sacerdotes llamados tiuniencha, y así iban todos éstos a las casas de los papas, y poníanse a las puertas de aquellas casas de los sacrificadores y colgaban allí sus calabazas, a las entradas de las puertas, e iban los sacerdotes que llevaban los dioses a cuestas y tocaban sus cornetas en los cues altos y a la media noche miraban una estrella del cielo y hacían un gran fuego en aquellas casas de los papas [... Y venía aquel sacerdote llamado hiripati y llegábase al fuego y tomaba aquellas pelotillas de olores y hacía la presente oración al dios del fuego:

Tú, dios del fuego, que apareciste en medio de las casas de los papas, quizá no tiene virtud esta leña que habemos traído para los cues, y estos olores que tenemos aquí para darte. Recíbelos tú, que te nombran primeramente mañana de oro, y a ti, Urendequanecara, dios del lucero, y a ti que tienes la cara bermeja. Mira que con grita trujo la gente esta leńa para ti. ${ }^{16}$

La Relación permite adentrarnos en el complejo sistema religioso tarasco y el papel especializado de los participantes. En esta liturgia, en la que actos, objetos y materiales estaban del todo preestablecidos, llama poderosamente la atención la omnipresencia de humo, aromas y sonidos musicales como medios para establecer contacto con lo divino y ofrendar. Sobre todo, destaca el humo; el encendido de leña para producir humaredas constituía un ritual por sí mismo y se efectuaba de modo casi permanente, salvo cuando moría el señor de la casa. ${ }^{17}$ La población entera, e incluso el mismo irecha, cuando era recién nombrado en ese cargo, tenía la encomienda de recolectar leńa, que se apilaba en

I6. Alcalá, op. cit., p. 239 (subrayado de la autora).

I7. Ibidem, p. 277. 


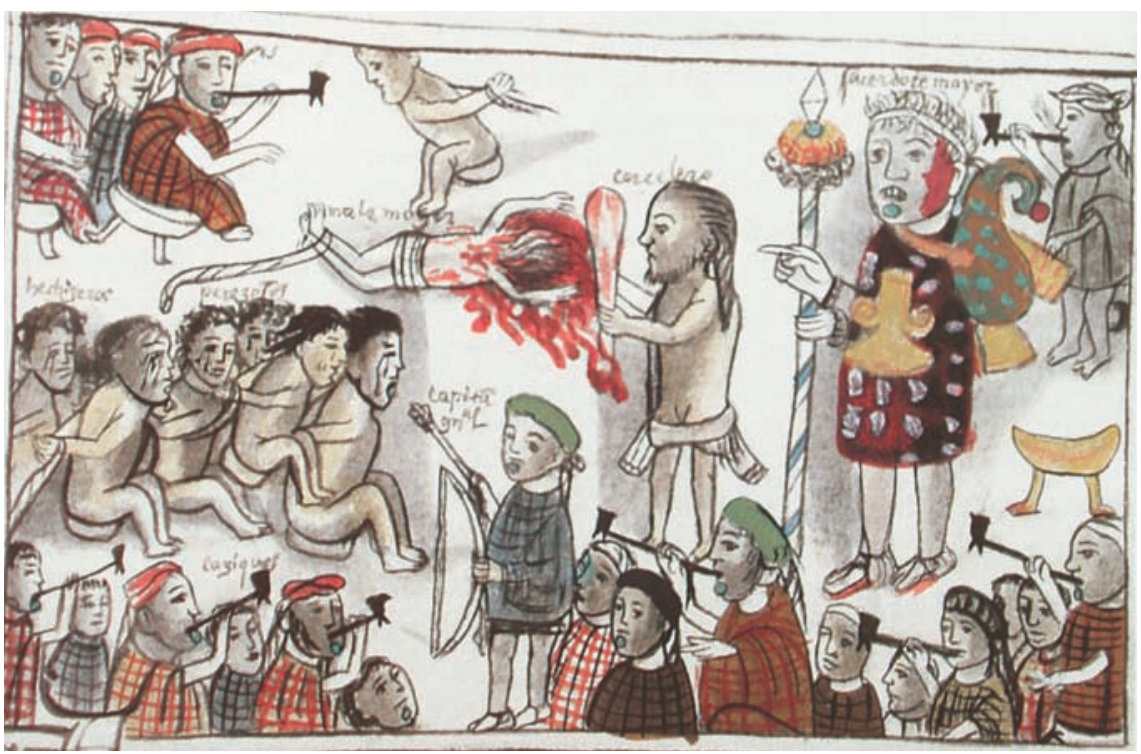

4. Escena de impartición de justicia, tomada de Jerónimo de Alcalá, Relación de Michoacán, Moisés Franco Mendoza (estudios y coord. de la edición), Zamora, Gobierno del Estado de Michoacán-El Colegio de Michoacán, 2000, lám. II [primera ed. ca. I 539-I 54I].

el "patio grande de los cues"; en tanto, el sacerdote mayor o petamuti "estaba diputado sobre la leńa de los fogones del dios del fuego" y los individuos comunes estaban obligados a tributarla, pues si dejaban de hacerlo cuatro veces se les encarcelaba. ${ }^{18}$ Además de las humaredas, en distintos rituales se acostumbraba hacer arder resinas olorosas — como se apunta en el pasaje anterior-, fumar tabaco y tocar instrumentos de viento, como flautas o cornetas y caracoles. En particular el acto de fumar se vincula con una escena de impartición de justicia, por medio del castigo y la ejecución, encabezada por el sacerdote mayor, en la que varios señores principales tienen pipas en la boca (fig. 4).

Considerando esta advocación de las yácatas junto con la vida ritual en la gran plataforma, de nuevo dirigimos la atención hacia las imágenes en los janamus. He mencionado que las espirales son el motivo más frecuente, ya sean simples o dobles divergentes y convergentes. La exploración iconográfica que he realizado en torno a las espirales revela una extensa gama de simbolismos. 
En diversas culturas indígenas las espirales simples representan viento, agua o animales asociados con agua, como serpientes y caracoles; también son el camino recorrido por los pueblos para encontrar su destino. Por su parte, las espirales dobles divergentes se asocian con movimientos migratorios que indican ida y vuelta, lo cual podría vincularse con hechos de la historia del pueblo tarasco. ${ }^{19}$

En abono a la polisemia de las formas espirales, planteo que, en el contexto particular de la cultura tarasca, uno más de los significados que es pertinente atribuirles se enlaza con el culto a Curicaueri, el dios del Sol y el Fuego al que se dedicaban las yácatas de Tzintzuntzan, y a quien, de acuerdo con la Relación de Michoacán, los tarascos rendían ofrendas de fuego, humo, música y aromas esparcidos, tal vez copal y tabaco. En mi opinión, las diversas espirales plasmadas en los janamus son quizá figuraciones de estos elementos volátiles e intangibles que alcanzaban lo divino y servían de intermediarias entre los ámbitos humano y sobrenatural; las espirales pudieron materializar los sonidos, los aromas y el humo que comunican a los hombres con los dioses.

\section{Una forma peculiar de ornamentación arquitectónica}

Tal como se dijo, resulta singular el acomodo disperso de los janamus grabados en las fachadas de los edificios. Entre los rasgos distintivos de esta ornamentación resalta que las lajas con imágenes no conforman paneles y tampoco siguen un orden simétrico. Dentro de la esfera del Estado tarasco, el uso superficial y diseminado de las losas decoradas con motivos geométricos simples en edificios prehispánicos se aprecia también en Ihuatzio y Pátzcuaro, y en sitios de jerarquía menor como Huandacareo, Acámbaro, Zitácuaro y otro fechado entre 700 y 900 d.C., llamado San Antonio Carupo. Aparte del ámbito tarasco, dentro de la región noroccidental mesoamericana hay casos similares en El Cóporo, Guanajuato, cuyo desarrollo máximo se produce entre 500 y 900 d.C., y otros posteriores a este último año, como Los Toriles, en Ixtlán del Río, Nayarit, y en el sur de Jalisco, en Terla y Cerritos. A mi parecer, en especial a partir de los testimonios tarascos, consiste en un tipo de decoración arquitectónica que fue más común en culturas de la fase Tardía o Posclásica. Fuera de la región occidental, un ejemplo se advierte en la segunda etapa constructiva del Tem-

I9. Cfr. Hernández Díaz, "Los janamus grabados...", op. cit. (véase n. Io). 
plo Mayor de Tlatelolco, en la ciudad de México. ${ }^{20}$ De tal manera, podría tratarse de una forma de expresión artística mesoamericana cuyo registro extenso está pendiente.

Por otra parte, centrando la atención únicamente en las losas decoradas de sitios relacionados con la cultura tarasca, me ha sido posible advertir lazos específicos con el arte rupestre. Mi argumentación se basa en los rasgos que caracterizan esta forma de ornato: en principio, el acomodo diseminado, sin orden aparente, de los janamus con imágenes en las fachadas de los edificios, y no sólo en los prehispánicos, pues en general lo mismo ocurre también en los virreinales, como se verá más adelante. Igualmente, en el predominio de la técnica del grabado y el hecho de que los diseños evocan motivos y rasgos estilísticos frecuentes en el arte rupestre, es decir, con tendencia a lo geométrico y geometrizante de las formas.

Tales elementos me sirven de base para formular la idea de que en la historia del arte tarasco se produjo una integración armónica entre lo rupestre y lo arquitectónico. Luego del estudio de distintas fuentes, es posible esbozar una explicación tentativa de tal síntesis, desarrollada de modo paulatino.

En la esfera de lo tarasco, una manifestación relativamente temprana se encuentra en Cerro Barajas, en el suroeste guanajuatense, cuya ocupación principal va de 650 a 950 d.C. y donde se reconocen antecedentes de los movimientos expansionistas purépechas en su afán de conquistar territorios más sureños. En este sitio se han detectado piedras con grabados, con frecuencia espirales, generalmente en las áreas habitacionales de la falda norte del cerro. ${ }^{2 \mathrm{I}}$

Ya en Michoacán, en el área centro-norte del estado, Brigitte Faugère-Kalfon señala que formas geométricas como espirales simples, líneas onduladas alargadas, círculos radiados, círculos concéntricos y retículas se plasmaron en obras rupestres por lo menos desde el siglo viI d.C. En particular, respecto a un sector de este territorio enumera 70 grabados rupestres y I34 petrograbados asociados a sitios arquitectónicos ceremoniales y de uso habitacional. De estos últimos, Io6 están en bloques naturales y sólo 28 son piedras que reci-

20. Se hace referencia precisa a los estudios que presentan estas evidencias arqueológicas en Verónica Hernández Díaz, Imágenes en piedra de Tzintzuntzan, Michoacán. Un arte prehispánico y virreinal, México, Universidad Nacional Autónoma de México-Coordinación General de Estudios de Posgrado (Colección Posgrado), en prensa.

2 I. Gregory Pereira et al., "Cerro Barajas, Guanajuato”, Arqueología Mexicana, vol. XV, núm. 87, septiembre-octubre de 2007, pp. 77-82; véase en particular la figura superior de la p. 80 . 
bieron preparación, es decir, que fueron talladas en forma rectangular. ${ }^{22}$ Aquí y en Cerro Barajas, a diferencia de Tzintzuntzan, el diseńo suele adoptar el contorno de la roca y el pulido de las superficies es mínimo, mientras que en Tzintzuntzan, como se ha visto, la mayoría de los motivos no ocupan la superficie total de los janamus.

El sitio más extenso de dicha área es San Antonio Carupo, donde se encontraron grabados en bloques cortados en formas rectangulares que luego se integraron en los muros (lo mismo sucede en el asentamiento cercano de Las Iglesias de Copítiro) y también grabados en afloramientos rocosos muy cercanos a los espacios arquitectónicos. ${ }^{23}$

$\mathrm{Al}$ igual que en el centro-norte michoacano, en Tzintzuntzan hay obras de arte rupestre vinculadas con el centro arquitectónico ceremonial. Más arriba de la gran plataforma, ascendiendo por el cerro Yahuarato, se conocen algunos conjuntos de petrograbados con motivos geométricos. ${ }^{24}$ Igualmente, en el costado noreste de la gran plataforma pueden verse grupos de rocas o piedras aisladas con formas grabadas. En conjunto, en los tres casos que conozco son comunes las series de líneas cortas horizontales colocadas verticalmente, simulando escaleras y confiriendo a las obras un carácter arquitectónico, como ocurre en las llamadas "maquetas". En uno de los grupos, este diseño se asocia con espirales simples y dobles divergentes (fig. 5a); en otro, se trata también de espirales, pero con extensiones de líneas curvas que configuran crestas y valles (fig. 5 b) $;{ }^{25}$ en el tercero, el mismo motivo se vincula con líneas que siguen curvas y rectas, una de las cuales parece una serpiente (fig. 5c). ${ }^{26}$

22. Brigitte Faugère-Kalfon, Las representaciones rupestres del Centro-Norte de Michoacán, México, Centre Français d'Études Mexicaines et Centraméricaines (Études Mésoaméricaines II-6), I 997.

23. Ibidem, p. 77.

24. Cfr. Cabrera Castro, op. cit., fig. I. Conviene agregar que, en el plano de la extensa zona arqueológica de Tzintzuntzan dibujado por este autor, se indican dos grupos de "petroglifos" más, ubicados al sur de las yácatas principales, más arriba del cerro Yahuarato.

25. Esta piedra es referida por Ramón Gali, quien la describe como ovoide, de $78 \mathrm{~cm}$ de largo y 55 de ancho; la encontró en el llamado barrio de San Pablo, al sureste de las yácatas principales; cfr. su ensayo "Arqueología de Tzintzuntzan", Anales del Museo Michoacano, Morelia, 2 a época, núm. 4, I946, pp. 429-445, en particular pp. 437-44I.

26. Jorge R. Acosta escribe sobre varios peñascos con grabados en la falda del cerro que baja al pueblo, pero sólo presenta el dibujo de dos. En la parte alta de la isla de Janitzio, en el lago de Pátzcuaro, muy cerca de Tzintzuntzan, también registró arte rupestre, y señala que sus motivos son similares a los de los monumentos de Tzintzuntzan y que fueron destruidos cuando se construyó la estatua de Morelos (Acosta, op. cit., pp. 9I-92). 
a)

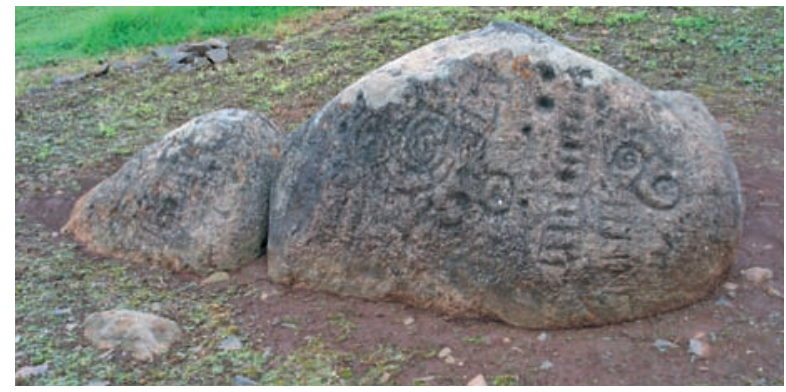

b)
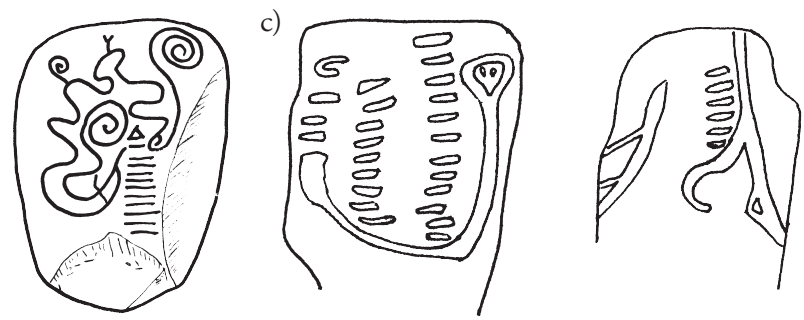

5. Grabados rupestres, zona arqueológica de Tzintzuntzan;

a) localizado del lado noreste de la gran plataforma. Foto: Verónica

Hernández Díaz, 2008; b) dibujo de Verónica Hernández Díaz, basado en Gali, op. cit., lám. 4 (supra n. 25); c) dibujo de Verónica Hernández Díaz, basado en Acosta, op. cit., fig. 7 (supra n. II).

Este breve panorama aborda un fenómeno de asociación de obras de arte rupestre a espacios arquitectónicos y lo que concibo como una paulatina integración directa a las construcciones y a los ámbitos urbanos; es decir, como piedras preparadas para ser parte visible de los muros de los edificios, pero cuya decoración continúa la técnica básica y las formas plasmadas en expresiones rupestres. En otras ciudades mesoamericanas cuyos edificios están recubiertos de imágenes pétreas, por lo común se trata de figuras en medio o alto relieve y, por tanto, su creación resulta más cercana a la escultura, ya que son de carácter tridimensional; además, en su disposición prevalece la simetría y la conformación de paneles o secuencias determinadas. En cambio, en los contextos rupestres, el grabado predomina entre las técnicas de ejecución para producir diseños hundidos o huecos, y con frecuencia aparentan una distribución dispersa.

A manera de síntesis, en sitios del Posclásico temprano, como San Antonio Carupo y Las Iglesias de Copítiro, ya se componen algunas paredes con pie- 
dras grabadas, talladas en forma rectangular, cuadrada u ovalada. Es durante el Posclásico tardío cuando reconozco una integración plena de lo rupestre y lo urbano, en las ciudades capitales que surgen después de la conformación definitiva del Estado tarasco. En Tzintzuntzan, Pátzcuaro e Ihuatzio, principalmente, se grabaron losas rectangulares o cuadrangulares, con la función particular de revestir construcciones. En un asentamiento secundario, como Huandacareo, no suele observarse ni el pulido ni la perfecta forma ortogonal de los janamus grabados de Tzintzuntzan y de las otras dos capitales.

En términos amplios, entre sus múltiples funciones, las imágenes rupestres marcan lugares sagrados. De acuerdo con ello, y al margen de su interpretación precisa, pienso que los janamus decorados en el centro ceremonial antiguo de Tzintzuntzan pudieron servir para sacralizar el espacio. No obstante, los diseños ahí plasmados no son de ningún modo exclusivos de estas artes en piedra, pues en el ámbito de la cultura tarasca hay motivos idénticos a los de los janamus en vasijas cerámicas asociadas con entierros de alto estatus; en particular, en la lámina II de la Relación de Michoacán pueden verse espirales que forman parte del diseńo de las pinzas de metal que porta el sacerdote mayor como un claro atributo de su jerarquía. De tal suerte, se afirma el valor simbólico de los motivos y se alcanza a vislumbrar su papel relevante en la ritualidad, las creencias y la visión del mundo de los tarascos.

\section{El convento franciscano y sus janamus decorados}

Entre los casos de arquitectura virreinal que conozco en Michoacán, sólo en Tzintzuntzan los janamus se reutilizaron a menudo para revestir los muros de la nueva arquitectura religiosa, en este caso impulsada por la orden franciscana. Igualmente, en el panorama extenso del México antiguo, no identifico otro caso donde obras prehispánicas con imágenes se hayan vuelto a emplear tan frecuente e incluso evidentemente, como en el convento de San Francisco, en Tzintzuntzan. En tal hecho advierto un notable indicio de continuidad cultural que trasciende el aprovechamiento práctico de materiales de construcción. De manera por demás interesante, el contexto histórico que rodea esa reutilización, principalmente durante el siglo XVI y los inicios del XVII, permite reconocer que, además del peso de la tradición, las creencias, los conceptos y las prácticas rituales y artísticas, hubo fuertes motivaciones políticas y económicas que inducirían en buena medida a emplear otra vez los janamus decorados. 
El recinto franciscano se ubica al pie del cerro Yahuarato, apenas a unos $300 \mathrm{~m}$ del antiguo centro ceremonial tarasco. Ocupa un área aproximada de 4 ha y sus edificios se hayan dispuestos en dos atrios, el principal y el hospitalario, que es más pequeño (fig. 6). En el primero se encuentran la antigua sede del monasterio, una capilla abierta, la iglesia de San Francisco, una portada aislada, el templo de la Virgen de la Soledad, I2 ermitas para la celebración del Vía Crucis, una cruz atrial y por supuesto el espacioso atrio. El segundo recibe su nombre por albergar la capilla del hospital, que es abierta y exenta, y se dedicó a Nuestra Señora de la Inmaculada Concepción; se ven también una cruz atrial, una pila bautismal por inmersión y la fachada lateral del templo de La Soledad. Tales son los monumentos novohispanos en el conjunto, cuya edificación tuvo lugar a lo largo de todo el periodo virreinal. George Foster señala que hasta 1766 el espacio se mantuvo bajo la jurisdicción de los franciscanos y luego pasó al clero secular. ${ }^{27}$

En todo el convento pueden apreciarse los janamus decorados. He registrado un total de 98, aunque con seguridad la cantidad es superior. ${ }^{28} \mathrm{La}$ mayoría de ellos se empotraron en los muros externos de los monumentos, así como en las paredes de los atrios, vistas desde los mismos patios (fig. 7). Conviene mencionar que, al igual que en el caso del antiguo centro ceremonial, he tomado en cuenta la movilidad de las piezas y he puesto gran atención en la historia de la construcción del conjunto, considerando las

27. George Foster, Los hijos del imperio. La gente de Tzintzuntzan, Zamora, El Colegio de Michoacán, 2000, p. 288 [primera ed. I948].

28. Para lograr este registro fue indispensable el apoyo del Centro Cultural Comunitario de Tzintzuntzan, que tiene bajo su cuidado el inmueble del actual ex convento franciscano. En particular, agradezco al profesor Filiberto Gómez Estrada, secretario del consejo de dicha asociación, y a la licenciada Tania Calderón, su coordinadora, las facilidades que me dispensaron para poder estudiar el convento y la valiosa información que me proporcionaron en octubre de 2008 . Expreso a ellos mi reconocimiento.

Los 98 janamus decorados que hasta ahora he identificado en el recinto franciscano resultan de dos registros realizados in situ, uno en 2000 y otro en 2008 . Durante el primero, casi la totalidad del monasterio estaba clausurada, debido a su deterioro profundo. Como el segundo registro tuvo lugar después de tareas de restauración, se me permitió ingresar a áreas antes cerradas y pude ver janamus antes cubiertos de aplanado (véase la nota que sigue), de tal manera que registré un mayor número de janamus decorados empotrados en los muros.

Tal como se dice arriba, la cantidad de este tipo de losas es mayor que la anotada, debido a que hasta la fecha permanece cerrado el paso a varias secciones del monasterio y porque ahí mismo hay una bodega — que no conozco- con janamus exentos. 


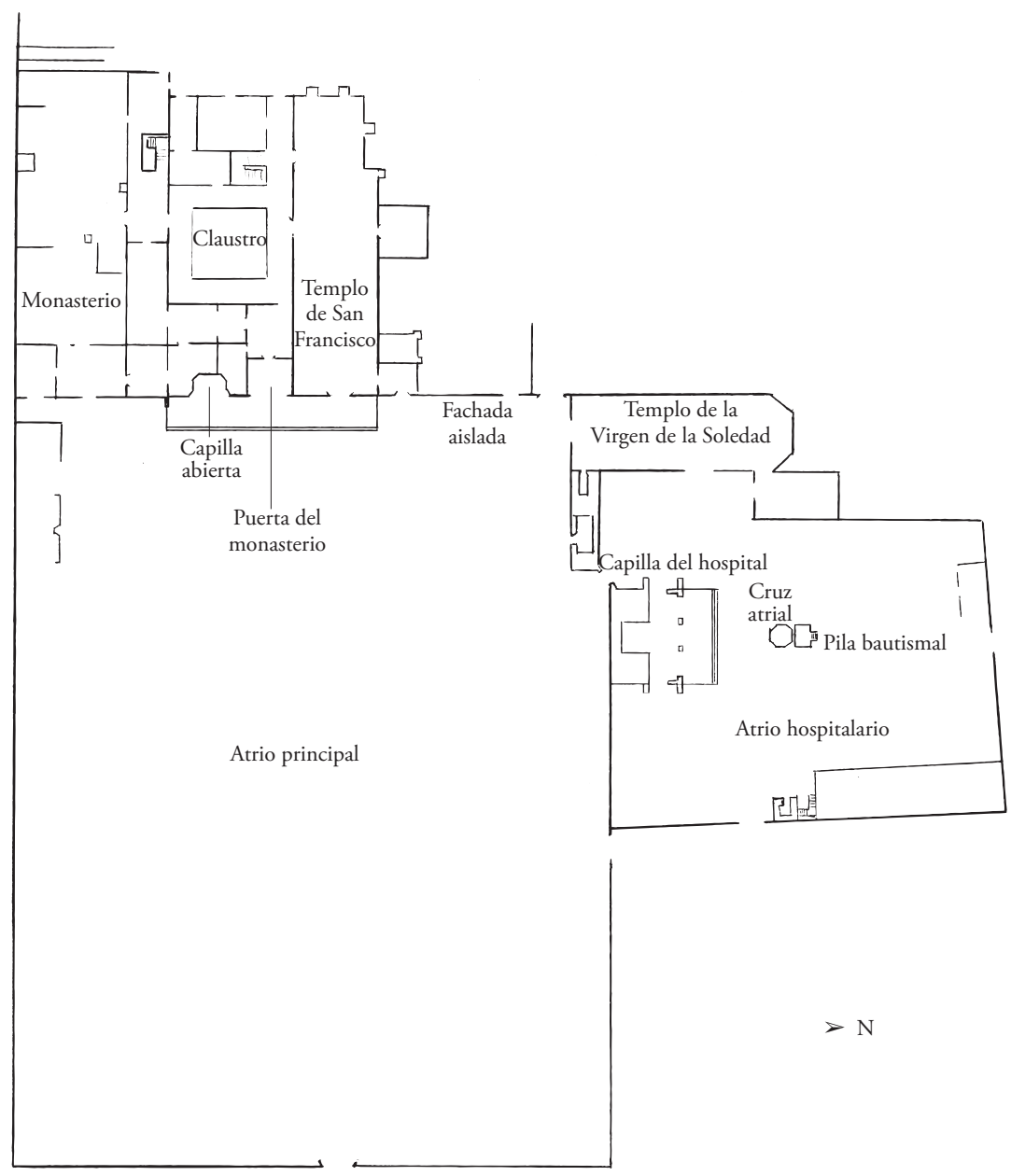

6. Plano del convento de San Francisco, Tzintzuntzan. Dibujo de Verónica Hernández Díaz, basado en Manuel Toussaint, Pátzcuaro, México, Universidad Nacional Autónoma de México-Instituto de Investigaciones Estéticas-Escuela de Arquitectura, 1942, p. 215, y en Esperanza Ramírez Romero, Catálogo de monumentos y sitios de Pátzcuaro y la región lacustre, México, Gobierno del Estado de Michoacán-Universidad Michoacana de San Nicolás de Hidalgo, I990, planos 82 y 85 . 


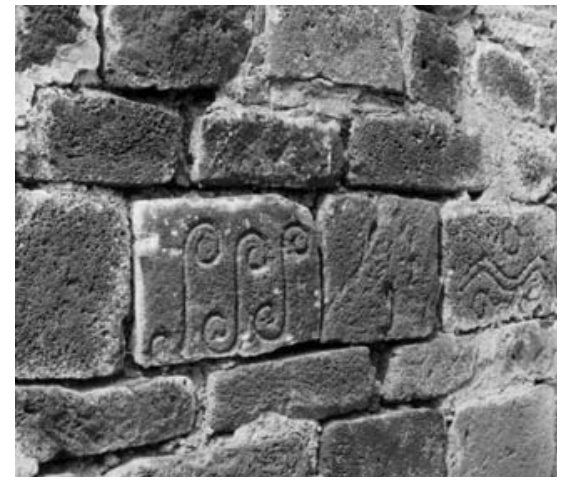

7. Janamus decorados empotrados en la portada de la capilla del hospital, convento de San Francisco, Tzintzuntzan. Foto: Verónica Hernández Díaz, 2000.

modificaciones principales que han experimentado algunos edificios en el curso del tiempo. ${ }^{29}$

Desconozco si a lo largo de sus tres siglos de historia estas piedras resultaban abiertamente visibles o estaban cubiertas; en la actualidad, algunas construcciones conservan restos de enlucido y otras tienen la piedra expuesta. Además del repertorio de imágenes asociadas con la zona arqueológica, en el convento se ven diseños "florales", "estrellas", círculos con rayos que semejan "soles", caracoles cortados transversalmente, combinaciones de líneas rectas y onduladas, figuras humanas (fig. 8) y aun motivos grabados o incisos durante la época colonial, como años y cruces cristianas (fig. 9). Hasta el momento, en mi registro, el amplísimo monasterio concentra el mayor número de estas obras, es decir, 45; le siguen la capilla del hospital con 19 y el templo de San Francisco con ro. El diseño predominante es la espiral con un solo giro en distintas modalidades derivadas de la clasificación formal que he realizado: individual, alineada, con vuelta interior o exterior particular, asociada con líneas curvas o círculos, o con líneas rectas y curvas. Al parecer, en comparación con los janamus decorados de la zona arqueológica, con fines de incorporar en el convento las losas, se redujeron las dimensiones de éstas: entre las que pude medir, la mayor alcanza sólo $30 \times 53 \mathrm{~cm}$ y la menor $17 \times 26 \mathrm{~cm}$.

29. Es importante señalar que desde 2004 se iniciaron exhaustivas labores de restauración del actual ex convento. En numerosos muros del conjunto, el aplanado se renovó y se dejaron sin cubrir los janamus decorados hallados tanto en el monasterio como en la portada del templo de San Francisco. Asimismo, cinco de los que se resguardan en una bodega dentro del convento se colocaron en el suelo frente a dicha iglesia, lo cual me ha permitido tomarlos en cuenta ahora. 

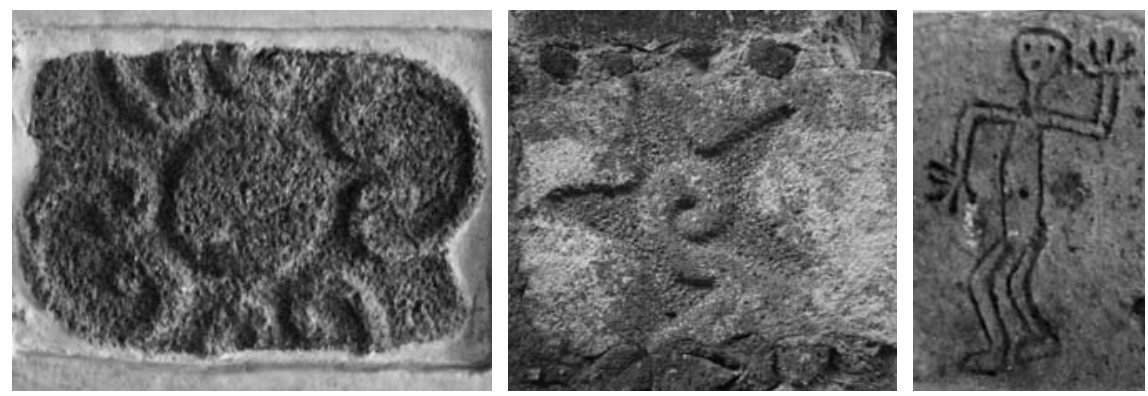

8. Janamus con diseńos figurativos empotrados en el convento de San Francisco,

Tzintzuntzan. Foto: Verónica Hernández Díaz, 2008.

El frecuente reúso se debe quizá a que el predominante estilo geométrico no figurativo de las losas facilitó su integración en los nuevos edificios religiosos. También podría afirmarse que continuaron siendo significativas las imágenes en piedra que originalmente integraban la arquitectura ceremonial. En este orden de ideas, un ejemplo sobresaliente es el janamu decorado empotrado en uno de los contrafuertes de la capilla abierta del hospital, pues exhibe una figura antropomorfa que he identificado como el Flautista, personaje característico de los pueblos indios del suroeste de Estados Unidos, también registrado en territorios del norte de México.

En el contexto cultural de Tzintzuntzan, la imagen del Flautista me remite a la presencia relevante de músicos que tocan instrumentos de viento en algunos de los rituales celebrados en el centro ceremonial antiguo, referidos párrafos atrás; asimismo, he establecido lazos con otros testimonios del Michoacán antiguo. Pero en especial interpreto su reutilización como una evidencia de los nexos que, según indagaciones arqueológicas recientes, entablaron los purépechas con culturas del norte. Al integrarse dicha imagen en la capilla del hospital, institución donde los indígenas tradicionalmente adquirieron gran preponderancia, tal vez se refleja la vigencia de la memoria histórica ligada a ella por parte de los tarascos. La intencionalidad que se manifiesta al reutilizarla, en mi opinión, se aprecia en el hecho de que justo frente al Flautista se halla un janamu cuyo diseño, de manufactura virreinal, es una letra A, que acaso aludía a una persona o grupo indígena, quizá una cofradía, a cargo del cuidado y la administración de la capilla del hospital. ${ }^{30}$ 

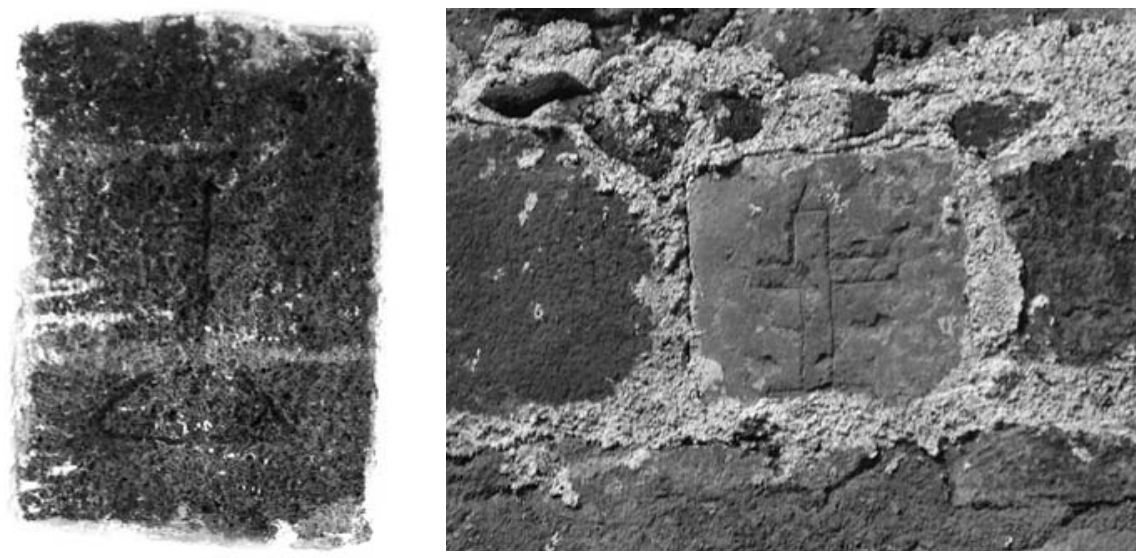

9. Janamus con cruces cristianas empotrados en el convento de San Francisco, Tzintzuntzan. El diseño que se ve a la izquierda se colocó originalmente en posición horizontal. Foto: Verónica Hernández Díaz, 2008.

En otros casos se reconoce cierta intencionalidad particular, pero no es oportuno extenderse en ellos aquí, donde se atenderán algunas circunstancias históricas surgidas después de la Conquista en Tzintzuntzan, que en general pudieron promover la integración de los janamus decorados en el convento.

\section{Los privilegios perdidos y la recuperación del pasado prehispánico}

La llegada de Cristóbal de Olid y su ejército a Tzintzuntzan en I 522 marca el inicio definitivo de la conquista espańola de Michoacán. En medio de una crisis de autoridad, los tarascos se rindieron en términos pacíficos; luego, sobrevino una etapa en que sufrieron los perjuicios de la encomienda, la esclavización, el saqueo a manos de los conquistadores y el exterminio provocado por las epidemias. ${ }^{31}$

A finales de 1525 , arribaron a Tzintzuntzan los primeros frailes franciscanos, encabezados por fray Martín de Jesús o de la Coruña. ${ }^{32}$ Casi en seguida, en

Tzintzuntzan, Michoacán”, Anales del Instituto de Investigaciones Estéticas, vol. XVIII, núm. 89, otońo de 2006, pp. 197-2 I 2.

3 I. La obra clásica sobre el tema es de J. Benedict Warren, La conquista de Michoacán, I 52 II530, Agustín García Alcaraz (trad.), Morelia, Fimax (Estudios Michoacanos, VI), I 977.

32. Ibidem, p. I I O. 


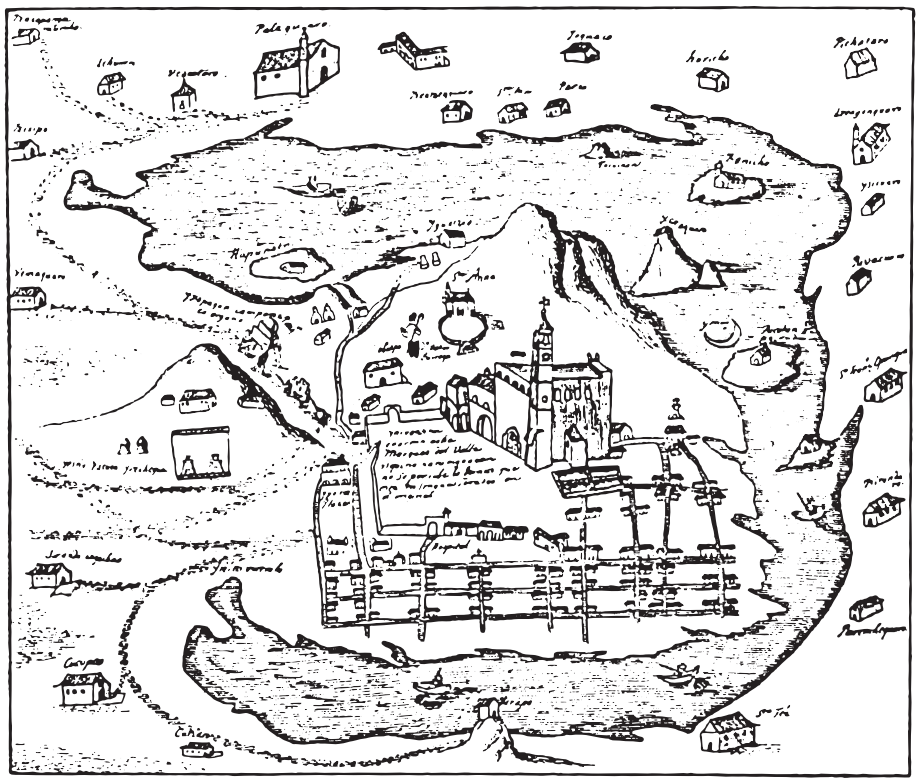

ıo. Mapa de la región del lago de Pátzcuaro (siglo Xvi) con Tzintzuntzan al centro. Tomado de Seler, Collected Works..., op. cit. (infra n. 50), p. 20, fig. 17 .

su primer establecimiento en la localidad, cobró cuerpo la nueva arquitectura religiosa: un templo dedicado a santa Ana se levantó de modo simple. ${ }^{33}$ En dos mapas históricos en que se mira el lago de Pátzcuaro y los sitios circundantes, con Tzintzuntzan en el centro de la composición (figs. Io y I I), aparece dicho templo identificado con glosas; se ve en las faldas del "cerro Tariaquari", con sus reducidas dimensiones y su atrio circular. ${ }^{34} \mathrm{~A}$ cierta distancia se encuentra

33. Cfr. Isidro Félix de Espinosa, Crónica de la provincia franciscana de los apóstoles san Pedro y san Pablo de Michoacán, apuntamientos bibliográficos de Nicolás León, Morelia, Universidad Michoacana de San Nicolás de Hidalgo-Instituto de Investigaciones Históricas/Morevallado, 2003 [primera ed. $c a$. I75 I].

34. De acuerdo con Helen Perlstein Pollard, es probable que ocupara la plataforma donde habría estado la residencia de Zinzicha Tangaxoan, el soberano tarasco, en el sector poniente de la localidad —en el actual barrio de Santa Ana—, fuera del centro ceremonial (op. cit., p. 38). Respecto a los ańos de I940, se informa que sólo quedaba una pila de rocas y una cruz de madera; véase Foster, op. cit., p. 272). 


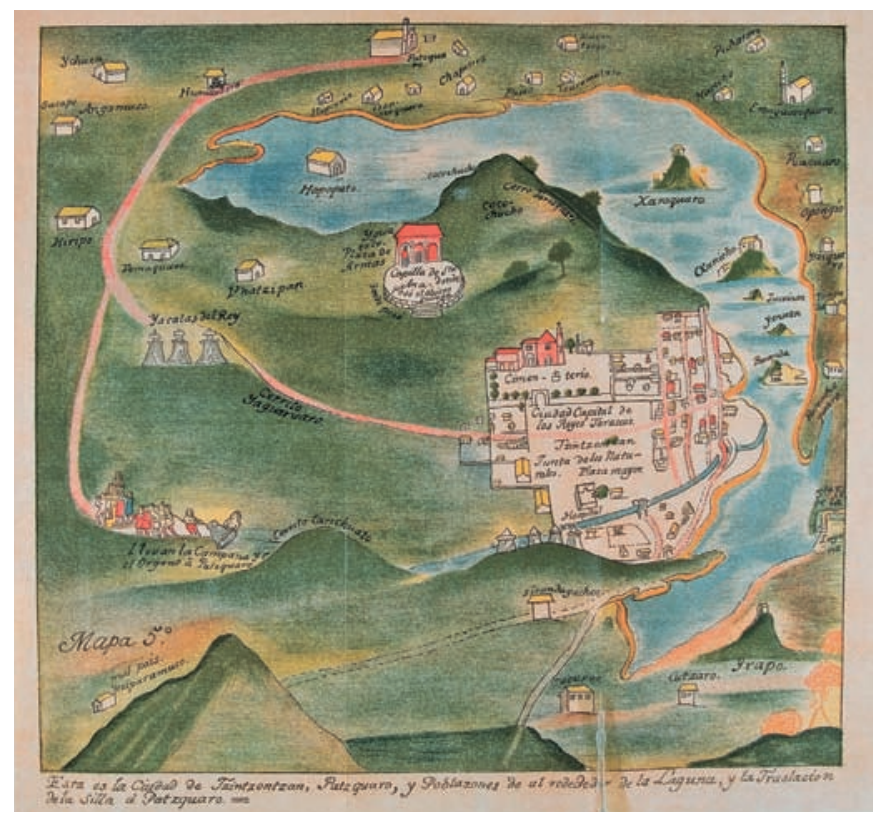

I I. Mapa de la región del lago de Pátzcuaro, tomado de Beaumont, Crónica de Michoacán, op. cit. (infra n. 5I), t. III, frente a p. 4IO. Foto: Gerardo Vázquez, 2008. Archivo Fotográfico IIE-UnAM.

el gran convento de San Francisco, por lo que se infiere el cambio de los religiosos al lugar actual. Es probable que hacia 1529 finalmente los franciscanos se asentaran ahí. ${ }^{35}$ Las primeras construcciones serían sencillas, ya que hasta la década de 1570 se ubica la construcción definitiva o permanente del gran conjunto cristiano, bajo la dirección de fray Pedro de Pila. ${ }^{36}$

Con base en el análisis de fuentes y en los estudios de la misma arquitectura, perfilo su temporalidad: la mayor parte de los edificios y la configuración de los espacios abiertos datan de las tres últimas décadas del siglo xvi y los primeros años del siguiente. A finales del xvi, podrían haberse levantado los muros del atrio principal, su cruz atrial y las pequeñas ermitas, el monasterio, la iglesia de San Francisco y las dos capillas abiertas. Luego de recientes tareas de res-

35. Warren, La conquista de Michoacán..., op. cit., p. I I6.

36. John McAndrew, The Open-air Churches of Sixteenth Century, Mexico. Atrio, Posas, Open Chapels, and Other Studies, Cambridge, Harvard University Press, 1965, p. 509. 
tauración ${ }^{37}$ en la fachada del templo de San Francisco, se dejó al descubierto, es decir, sin aplanado, un janamu grabado con el año "I6or", que seguramente indica la fecha de terminación. La capilla de Nuestra Señora de la Concepción tiene en su portada una inscripción que incluye el año I6ı9; ya en la época contemporánea, en el atrio hospitalario pudieron hacerse los muros perimetrales, la cruz atrial y la pila bautismal. El estilo de las portadas del templo de la Virgen de la Soledad permite determinar que se construyeron en lo fundamental durante el siglo XVII, aunque no se concluyeron hasta I805, según el año inscrito en el remate del segundo cuerpo de la fachada principal.

Al comienzo de la dominación española se reconoció la supremacía política de Tzintzuntzan, por su condición de ciudad principal de los tarascos en el momento del arribo de los españoles. A partir de una solicitud del entonces oidor Vasco de Quiroga, en I534, la monarquía española le concedió formalmente el título de "ciudad de Michoacán", ${ }^{8}$ con lo cual continuó siendo la capital de la región, donde residían las autoridades indígenas e hispanas, tanto políticas como religiosas. Sobre la reorganización social, conviene aclarar que, aun cuando los pueblos michoacanos se sometieron a corregidores y alcaldes españoles, siguieron contando con autoridades indígenas propias y así los miembros principales del linaje purépecha se mantuvieron en el gobierno de la provincia michoacana hasta las postrimerías del siglo XVII. ${ }^{39}$

Entre los sucesos que señalan la relevancia de la elite indígena en Tzintzuntzan figuran las acciones que emprendió para devolverle el título de ciudad, perdido en 1538 a instancias del recién nombrado primer obispo de Michoacán, Vasco de Quiroga. El 6 de agosto de ese año, el prestigiado abogado y benefactor de los indígenas tomó posesión de su diócesis en la iglesia de San Francisco de Tzintzuntzan y al día siguiente, al trasladar la sede episcopal a Pátzcuaro, se llevó con ella el rango de ciudad capital, por lo cual Tzintzuntzan también dejó de

37. Véase n. 29.

38. Rodrigo Martínez Baracs, Convivencia y utopía. El gobierno indio y español de la "ciudad de Mechuacan”, I52I-I 580, México, Fondo de Cultura Económica/Instituto Nacional de Antropología e Historia, 2005, pp. 23 I-233. En su papel de oidor, Vasco de Quiroga ya había estado en Tzintzuntzan en I 533 (ibidem, p. 217).

39. En I 696 falleció el gobernador Constantino Bravo Huitzimengari II, último descendiente del irecha Zinzicha Tangaxoan. Cfr. una obra fundamental sobre el tema: Delfina Esmeralda López Sarralangue, La nobleza indígena de Pátzcuaro en la época virreinal, México, Universidad Nacional Autónoma de México-Instituto de Investigaciones Históricas (Serie Historia Novohispana, 29), I965. 
ser el asiento de los poderes del orden civil..$^{40} \mathrm{La}$ pérdida fue catastrófica para esa población en lo político, social y financiero, puesto que se convirtió en un simple barrio de Pátzcuaro y estaba obligado a pagarle tributo. Se generó así una intensa pugna de poder, que enfrentó a indígenas de la misma localidad y de las dos concernidas, así como a Vasco de Quiroga con los franciscanos, quienes además le disputaban el establecimiento de los hospitales en Michoacán. ${ }^{4 I}$

\section{La arquitectura en el alegato}

Lo que he investigado me permite subrayar que la arquitectura del convento franciscano, e incluso la del antiguo centro ceremonial de Tzintzuntzan, fue pieza sustancial en el conflicto entre diversos bandos. En principio, el templo de Santa Ana, primera fundación de los franciscanos en Tzintzuntzan, es referido en los documentos que conformaban la probanza de Quiroga para justificar sus acciones. En su calidad de obispo, se le había asignado como catedral este templo, del cual se quejaba diciendo que se ubicaba en lo alto de un "valle hondo y lleno de barrancas" cuyo acceso resultaba muy complicado, y asimismo de que "la dicha iglesia es de adobes y de paja y vieja y pequeña como una pobre casa pajiza”. ${ }^{42}$

No obstante, ya en 1538 ese establecimiento había sido abandonado por los frailes; la iglesia de San Francisco estaba situada en la parte baja y plana del valle — puede suponerse que en el sitio actual—, más adecuada para edificar un convento accesible para toda la población. Varios testimonios señalan que, antes de su asentamiento definitivo, los franciscanos erigieron "otras iglesias en otras partes". 43

Entre los argumentos que Quiroga invoca en I 538 para cambiar la sede del obispado de Tzintzuntzan a Pátzcuaro, figura el de que no había "en la dicha ciudad fundada iglesia ni fundación ni población que de provecho sea", y sobre la edificación de los frailes señala que por el traslado no habría "cosa hecha que se pierda", puesto que era "de adobes y de paja, paupérrima y muy pequeña,

40. Warren, Estudios sobre el Michoacán colonial..., op. cit., pp. 79-85.

4I. Un extenso y acucioso libro sobre la disputa por el título de ciudad de Michoacán, entre otros temas, es el de Martínez Baracs, op. cit.

42. Warren, La conquista de Michoacán..., op. cit., pp. I I 5-I I 7.

43. "Información de don Vasco de Quiroga sobre el asiento de su iglesia catedral, I 538 ", transcrito en ibidem, apéndice X, pp. 439-457. 
donde todo edificio que en ella se hiciese, acrecentase o edificase sería perdido por las razones y causas que dichas son, así de mal asiento, como de la mala disposición y falta de agua y destemplamiento de aires que en ella corren”. ${ }^{44}$ Es notable el claro desprecio de que son objeto la arquitectura franciscana y el sitio de Tzintzuntzan.

Un problema derivado de ello sucedió a mediados de la década de I540, cuando Quiroga mandó llevar a Pátzcuaro un órgano que pertenecía a la iglesia de San Francisco de Tzintzuntzan y los pobladores locales impidieron el traslado. ${ }^{45}$ El hecho se representó en la sección izquierda de los mapas mencionados. Estos documentos podrían haber formado parte de la defensa emprendida no sólo por la elite indígena de Tzintzuntzan, sino también por los frailes franciscanos.

Delfina Esmeralda López Sarralangue dio a conocer que, en 1567, algunos nobles de Tzintzuntzan formularon un alegato para probar el estatus de ciudad capital de la localidad desde antes de la llegada de los españoles y durante los primeros años del virreinato. ${ }^{46} \mathrm{Su}$ argumento principal era la primacía prehispánica del asentamiento, pues justificaba que después de la Conquista éste se mantuviera como capital de la provincia michoacana. Hans Roskamp refiere, en un acucioso análisis, que, como parte de este proceso de afirmación prehispanista, Tzintzuntzan adoptó un nuevo escudo de armas donde se destaca la presencia de gobernantes purépechas vestidos como chichimecas o uacúsechas, ${ }^{47}$ claro testimonio de su pasado guerrero e invencible. Desde mi perspectiva, el uso, durante el siglo XVI y principios del XVII, de los janamus con imágenes de origen prehispánico en el convento de San Francisco se inscribiría en dicho contexto histórico. En lo básico, desde el plano de lo material, la reutilización fue parte intrínseca de la magna empresa arquitectónica que implicó la fabricación definitiva de dicho convento. Como ya se señaló, ésta se inició en la

44. "La posesión que se tomó en Pátzcuaro para la translación de la iglesia", publicado en Warren, Estudios sobre el Michoacán colonial..., op. cit., pp. 89-94, en particular 90-9I.

45. Ibidem, pp. 87-88.

46. López Sarralangue, op. cit., p. 64.

47. Hans Roskamp, "Pablo Beaumont and the Codex of Tzintzuntzan: A Pictorial Document from Michoacan, West Mexico", en Maarten Jansen y Luis Reyes García (coords.), Raymond Buve (ed. técnica), Códices, caciques y comunidades, Ridderkerk, Asociación de Historiadores Latinoamericanistas Europeos (AHILA) (Cuadernos de Historia Latinoamericana, 7), I997, pp. 209-2 I I.

Uacúsechas son los "señores águila" (Alcalá, op. cit., p. 279), grupo dirigente de los purépechas venidos del norte — por tanto "chichimecas" —, que dominó la región de Michoacán y gobernó al Estado tarasco. 
década de I570, al poco tiempo de que la gente de Tzintzuntzan había planteado su alegato.

El conflicto se prolongó y el resultado no fue del todo afortunado para los que abogaban por Tzintzuntzan, que hasta 1593 no recuperó el título de ciudad, aunque nunca más recobró el de capital; no obstante, pudo liberarse de la sujeción a Pátzcuaro y elegir a su gobernador. ${ }^{48}$ Por lo que toca a esta última población, desde 1576 había perdido la categoría de capital, pues, contra los afanes de Vasco de Quiroga, el virrey Antonio de Mendoza logró que ella se asentara en Guayangareo (hoy Morelia). ${ }^{49}$

\section{El convento: la arquitectura plasmada y la construida}

Retornando al asunto del alegato, es probable que, mediante los dos mapas antes referidos y la arquitectura que realmente se edificó, los tzintzuntzeños hayan intentado desmentir las opiniones del obispo. Las similitudes entre estos dos documentos pictóricos evidencian que tuvieron como modelo una misma imagen, con seguridad realizada $c a$. I545, ya que se representó el traslado del órgano y las campanas del convento franciscano de Tzintzuntzan a Pátzcuaro.

El mapa de tinta negra fue hallado por Eduard Seler en México a finales del siglo XIX..$^{50} \mathrm{El}$ segundo, al igual que otras nueve escenas históricas, se publicó en la edición de 1932 de la Crónica de Michoacán del franciscano fray Pablo de la Purísima Concepción Beaumont; ${ }^{51}$ debe hacerse notar que esas ilustraciones son copias, hechas hacia $1792,5^{52}$ de la que hizo Beaumont por lo menos I4

48. Martínez Baracs, op. cit., p. 260.

49. Ibidem, pp. 287 y ss.

50. Contiene glosas en purépecha y español. Se desconoce su paradero, pero lo publicó Eduard Seler en I905; véase “The Ancient Inhabitants of the Michuacan Region”, en Collected Works in Mesoamerican Linguistics and Archaeology, 5 vols., Culver City, Labyrinthos, I993, vol. IV, p. 20.

5I. Beaumont, Crónica de Michoacán, México, Secretaría de Gobernación (Publicaciones del Archivo General de la Nación, XVII), Talleres Gráficos de la Nación, I 932 [terminada hacia I778].

52. John B. Glass y Donald Robertson, "A Census of Native Middle American Pictorial Manuscripts", en Robert Wauchope (ed. gral.), Handbook of Middle American Indians. Guide to Ethnohistorical Sources, Howard F. Cline (ed. del vol.), Austin, University of Texas Press, I975, vol. I4, parte 3, p. 94 . 
años antes ${ }^{53}$ de la "pintura antigua en pergamino que conserva un indio [de Tzintzuntzan] llamado Cuini, descendiente de los nobles o primeros caciques de aquella corte" ${ }^{54}$ La conjunción de las nueve escenas históricas y del mapa del lago de Pátzcuaro copiados por Beaumont ha sido denominada por Roskamp "Códice de Tzintzuntzan".55 Con gran acierto, este autor ha estudiado esos documentos como una unidad y considera que podrían haber formado parte del alegato sobre la información y probanza de la ciudad de Tzintzuntzan registrada en $1567^{56}$ (referida arriba).

A partir del estudio de la arquitectura del convento de San Francisco, opino que el mapa original pudo elaborarse después de esa fecha, hacia los últimos años del siglo XVI, cuando ya se había concluido o estaba muy avanzada la construcción definitiva del monasterio, la iglesia de San Francisco, las dos capillas abiertas y los espacios abiertos de los dos atrios del recinto y sus muros perimetrales. Estos edificios, a excepción de la capilla adosada al monasterio, están representados — no fielmente — en el mapa de Seler, que se reconoce por su mayor apego al modelo original del siglo XVI. Llama la atención que Beaumont no dibujara con mayor exactitud el convento franciscano tal como estaba a finales del siglo XVIII, en tanto modificó su orientación, omitió el atrio hospitalario y su capilla y separó del conjunto un edificio que llama "hospital". En cambio, sí incorporó un elemento contemporáneo suyo: el templo de la Virgen de la Soledad, que ubicó hacia la derecha del de San Francisco.

53. Roskamp (op. cit., p. 195) apunta que alrededor de 1778 el fraile pudo estar concluyendo su crónica, y que dos años después murió.

54. Beaumont, op. cit., vol. II, p. 25. La copia, en varias secciones, que hizo Beaumont de esta pintura ha desaparecido, a excepción de una escena que se encuentra en la Biblioteca John Carter Brown, de la Universidad Brown, Providence, Rhode Island. Esta imagen se reprodujo en la portada y en el interior del libro de J. Benedict Warren, Estudios sobre el Michoacán colonial. En esta obra no hay referencia alguna a la autoría original de Beaumont de esta pintura. De modo previo, Glass y Robertson (op. cit., p. 94) mencionaron escuetamente que parte del manuscrito del cronista estaba en dicha biblioteca.

55. Un antecedente de dicho título es el de "Códice de la Conquista de Michoacán”, con el cual se resguardó en el Museo Nacional de Antropología, de la ciudad de México, una copia sin color de las nueve escenas históricas en una larga tira (así lo informan Glass y Robertson, op. cit., p. 94).

56. Roskamp, op. cit., p. 237. Antes, J. Benedict Warren refirió que en este alegato se insertó una de las escenas históricas de dicho "Códice", donde se ve el encuentro de fray Jerónimo de Alcalá y el obispo Vasco de Quiroga; véase Warren, La conquista de Michoacán..., op. cit., p. I I 5. 
$\mathrm{Al}$ igual que Roskamp, considero que la imagen que sirvió de modelo a estos dos mapas, y de la que ambos rinden testimonio, responde en efecto a la compleja situación política imperante en Tzintzuntzan después de la Conquista, que obligaría a los habitantes de ella a probar su jerarquía superior tanto en la época prehispánica como durante la dominación hispana. En lo particular, distingo que la representación pictórica de la arquitectura de ambos periodos tuvo un papel cardinal en este proceso de autorreconocimiento por parte de miembros del linaje purépecha de la localidad.

Especialmente en el mapa de Seler se configuraron las dimensiones monumentales y la solidez constructiva del convento franciscano, con su enorme atrio principal, espacio que pudo propiciar el sentido de colectividad e identidad de los tzintzuntzeños, en remembranza del antiguo centro ceremonial tarasco, con su vasta explanada. El ordenamiento del resto del asentamiento novohispano también se plasmó, la traza reticular evidencia su integración al sistema urbanístico europeo, aunque debe subrayarse que la imagen podría no expresar el estado de las edificaciones en Tzintzuntzan en ese momento. De ahí el valor del arte como una realidad por sí misma.

\section{La vigencia de lo prehispánico}

Como un sustento más de la relevancia de la arquitectura en esta pugna por los privilegios de una ciudad capital, en los mapas se figuraron construcciones prehispánicas por el afán de brindar testimonio del esplendor de Tzintzuntzan. En el de Seler, hacia la izquierda de la composición, el pintor representó el antiguo centro ceremonial tarasco en las faldas del cerro Yahuarato. Su equivalente, en el mapa basado en el de Beaumont, lleva escrita la leyenda "yacatas del rey" y su diseño está simplificado, pues sólo se ven dos yácatas dispuestas sobre una gran plataforma cuadrangular, donde, sin embargo, se aprecia la gran explanada o el "patio de los cinco cues grandes". A escasa distancia se pintaron otras dos yácatas registradas arqueológicamente en la misma ladera del cerro Yahuarato, un poco más arriba de la gran plataforma. Asimismo, otras pirámides se distribuyen en el territorio representado.

En esta interrelación entre las imágenes pintadas de la arquitectura y la arquitectura construida, en lo concerniente a lo prehispánico cabría insertar la extensa reutilización de los janamus, en especial los decorados, que ornamentaban las construcciones antiguas, tentativamente las del centro ceremo- 
nial. En suma, las evidencias anteriores parecen revelar una decidida estrategia que exaltaba el antiguo esplendor de Tzintzuntzan, de acuerdo con la versión de los nobles purépechas que defendían los intereses de esta localidad.

Como apoyo de esta interpretación, Roberto Martínez Baracs ha planteado —atendiendo otra línea de estudio- que la Relación de Michoacán constituyó una respuesta "tzintzuntzanista" a la información que en 1538 presentó Vasco de Quiroga para ponderar las cualidades de Pátzcuaro. ${ }^{57} \mathrm{La}$ fecha de su realización, que se inicia en I539, justo al año siguiente en que comienza la disputa con Pátzcuaro y el obispo Quiroga, coincide perfectamente con los conflictos históricos ya señalados. El documento se elaboró a petición del virrey De $M_{\text {Mendoza }}{ }^{58}$ y en él se adopta el punto de vista de la elite purépecha dirigente de Tzintzuntzan,59 ciudad a la que siempre se denomina "Mechoacan" para subrayar su carácter de capital de la provincia y su posición superior a la de Pátzcuaro y otras poblaciones. La obra resulta sumamente interesante, pues conjunta discursos diversos: con el fin de sostener su antiguo estatus, a lo largo de la narración la elite purépecha de Tzintzuntzan destacó su avanzado nivel de civilización y su legendario carácter guerrero, a la vez que el pacífico recibimiento dispensado a los españoles y la cooperación que les brindó durante la Conquista.

En torno a los janamus, pienso que su reutilización en el convento se ligó principalmente con los indígenas, activos constructores del recinto. Con seguridad contaron con la aprobación de los frailes franciscanos, poseedores de un espíritu humanista y cercanos a las tradiciones nativas en el marco de sus tareas evangelizadoras, y especialmente aliados con los nobles purépechas en su disputa contra Vasco de Quiroga. Durante la lenta fabricación del conjunto, el empleo de janamus antiguos constituyó una práctica persistente y, en el caso de los edificios levantados mediante labores constructivas más tardías, es interesante notar que se conservaron los que formaban parte de las obras previas. Puede conjeturarse que las losas decoradas de la arquitectura prehispánica abundaban y, también, que se seguía reconociendo en ellas un valioso legado.

57. Martínez Baracs, op. cit., p. 304.

58. Alcalá, op. cit., "Prólogo".

59. Hans Roskamp subraya este punto de vista de la historia, tanto en la Relación como en otros documentos pictográficos, como la serie de imágenes copiadas por fray Pablo Beaumont y publicadas en su Crónica de Michoacán; véase Hans Roskamp, La historiografía indígena de Michoacán. El lienzo de Jucutacato y los títulos de Carapan, Leiden University-Research School CNws, I998, cap. I. 
A finales del siglo XviII, fray Pablo Beaumont narró su recorrido por el centro ceremonial antiguo de Tzintzuntzan, en las faldas del cerro Yahuarato. Así se refiere a las cinco yácatas y al celo con que los pobladores locales cuidan sus monumentos:

hay cinco cerrillos o cuicillos que llaman los yacatas de piedra laja hechas a mano, en que regularmente no falta un indio como de custodia, y los indios aun en el día [de hoy] no permiten desentrañar estos cimientos. Hubo un clérigo indio llamado Domingo Reyes Corral, a quien obedecían los indios, y éste se puso de propósito a desentrañar las yacatas, y en un pedazo que cavó como de ocho varas en cuadro, sacó mucha piedra labrada; murió, y los indios luego taparon el hoyo, y no han consentido a otro alguno que allí cavaran. ${ }^{60}$

\section{Reflexiones finales}

Adaptándose a las nuevas circunstancias, en medio de una catástrofe y de la pérdida de su jerarquía, la gente de Tzintzuntzan, con los nobles purépechas a la cabeza, impulsó un notable proceso de continuidad de su cultura prehispánica, en su afán de sostener los méritos de la capital principal del poderoso e invencible Estado tarasco. Como parte de una creativa estrategia de supervivencia, que como se ha visto aquí abarcó diversas vertientes, resulta válido pensar que siguieron siendo significativos los janamus y las imágenes grabadas que integraban los principales edificios ceremoniales tarascos de la localidad. Atestiguamos así la persistencia de un peculiar estilo de ornamentación arquitectónica que remite al arte rupestre. Gracias a sus valores simbólicos, rituales e históricos, los janamus podrían haberse empleado con fines políticos y económicos, en aras de la magna empresa de construcción del grandioso convento de San Francisco. En tal sentido, cabe señalar algunas semejanzas cualitativas, formales y funcionales entre los dos centros ceremoniales referidos, que contribuirían a la notable unión de lo prehispánico y lo virreinal, de la religiosidad antigua tarasca y la cristiana.

Por supuesto, ambos recintos revisten un carácter sagrado, con templos dedicados a dioses o personajes relacionados con la divinidad; su diseño arquitectónico confiere una enorme importancia a extensos espacios abiertos —la

6o. Beaumont, op. cit., t. II, p. 46. 
explanada y los atrios-, capaces de alojar a cantidades masivas de personas y adecuados para la realización de procesiones, entre muchas otras actividades; asimismo, los dos contaban con construcciones que albergaban a los sacerdotes y funcionaban como cementerios.

En fin, los dos centros ceremoniales son testimonios singulares de la cultura tarasca y de la mestiza que se gestó a partir de la Conquista española. El actual ex convento continúa siendo el eje central de las diversas actividades sociales en Tzintzuntzan; la comunidad acude a él y convive cotidianamente con sus edificios, árboles, santos, dioses y piedras. En lo que respecta a los janamus decorados, puede advertirse en nuestros días una nueva recuperación del pasado prehispánico. A raíz de las acciones de restauración emprendidas desde 2004, se han dejado visibles losas con grabados que estaban empotradas en los muros y que en algún momento se cubrieron de aplanado. Poco a poco, a siglos de su creación y de su reempleo, estas obras reciben de nuevo luz. Gracias a ello es posible aproximarnos a ellas para procurar entender tanto su faceta tarasca

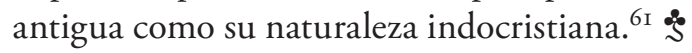

6r. Hasta antes de la investigación de mi tesis (véase n. Io) y de la continuación del estudio que he llevado a cabo, estas obras habían recibido muy escasa atención, en especial las del convento. 